\title{
$\mathrm{C} 13$ 熱音響発電への適用を目指したリニア発電機の研究
}

\section{Development of High-Efficiency Linear Alternator for Thermoacoustic Engine}

\author{
○正 星野 健(JAXA) 納富 信(早大) \\ 鈴木 啓史(早大) 吉原 正一(JAXA)
}

\author{
Takeshi HOSHINO, Japan Aerospace Exploration Agency, Jindaiji-Higashi 7-44-1, Chofu, Tokyo \\ Makoto NOHTOMI, Waseda University \\ Keishi SUZUKI, Waseda University \\ Shoichi YOSHIHARA, Japan Aerospace Exploration Agency
}

\begin{abstract}
Test models of free piston Stirling engine (FPSE) converter have been developed as heat-to-electricity power converters for a demonstration of solar heat energy utilization at the Japan Aerospace Exploration Agency (JAXA), for future aerospace applications. In the case of the FPSE, the output power of the working gas is directly used as the linear alternator input and then converted into electrical power. Therefore, the linear alternator is one of the most important devices in the FPSE. On the other hand, thermo-acoustic engine (TAE) is a technology that uses high-amplitude sound waves induced by a temperature difference. The work of the sound waves can be converted to electricity by a highly efficient linear alternator. Therefore, the linear alternator is also a key component for the TEA. To realize efficient linear alternators that are suitable for the TAE, several types of linear alternators have been designed and developed based on JAXA's FPSE technology. In this study, the performance evaluations of the linear alternators were conducted.
\end{abstract}

Key Words: Free Piston Stirling Engine, Linear Alternator

\section{1. はじめに}

フリービストンスターリングエンジンは, クランクやカム などのメカニズムを用いることなく，ビストンに直接負荷を 取り付けることによって，直線運動をそのまま利用すること が可能なスターリングエンジンである. 発電システムとして 考えた場合, リニア発電機を組み合わせることにより, パワ 一ビストンに作用する動作ガスの出力を直接的に発電機入 カとして用いることが可能であり, 通常のキネマティックエ ンジンと比較して高い総合効率が期待できる. そのため, JAXA では, 将来の宇宙用の熱発電機の一つとして研究開発 を続けてきた. 特に, リニア発電機は, システム全体の特性 や効率を支配する重要なコンボーネントのため, その研究開 発を継続して実施している ${ }^{1)}$.

一方、熱音響エンジンは、スターリングエンジンと同様に 温度差によって引き起こされる, 動作ガスの自励振動による 圧力変化を利用して動力を取り出すことが可能である. 一般 に動作周波数はスターリングエンジンよりも高く，いわゆる 音波と言われる領域である. 出力を電力として取り出すため には, 音波から電力に高効率に変換可能なりニア発電機が必 要である.したがって, フリービストンスターリングエンジ ンの場合と同様にリニア発電機は重要なコンボーネントで ある.ただし, これまで, 実際にリニア発電機を用いて出力 を電力として取り出した研究は, あまり行われていない. そ の理由は, 高効率でかつ熱音響エンジンに適したリニア発電 機の実現が，簡単ではないためであると考えられる。

そこで本研究では，これまでのフリービストンスターリン グエンジン用のリニア発電機の研究開発で蓄積した技術を 元に，熱音響エンジンに適したリニア発電機を試作した。ま た, リニア発電機の性能を詳細に検証できる, リ二ア発電機 試験装置を用いて，その性能の把握を試みた。

\section{2. 熱音響発電機の概要}

本研究の対象とする熱音響エンジンは, 早稲田大学で研究

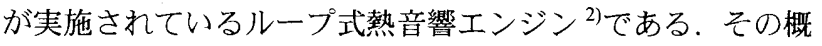
略を図 1 に示す。

全長 $4200 \mathrm{~mm}$ のルーブ式熱音響発振器であり, 動作ガスは アルゴンで, 圧力は $300 \sim 600 \mathrm{kPa}$ である. 加熱は, 内部に設 置した電気ヒータによって行っている. また, スタック材料 は, SUS304 のスクリーンメッシュを積層して用いている. 循環流の防止のためゴム膜等の挿入が可能となっている.

これまでの研究により熱から音波 (圧力振動) への変換効 率は，11\%以上を達成している，標準的な実験条件での発振 周波数は $75 \mathrm{~Hz}$ 程度であるためリニア発電機はそれに合わせ たものとした。

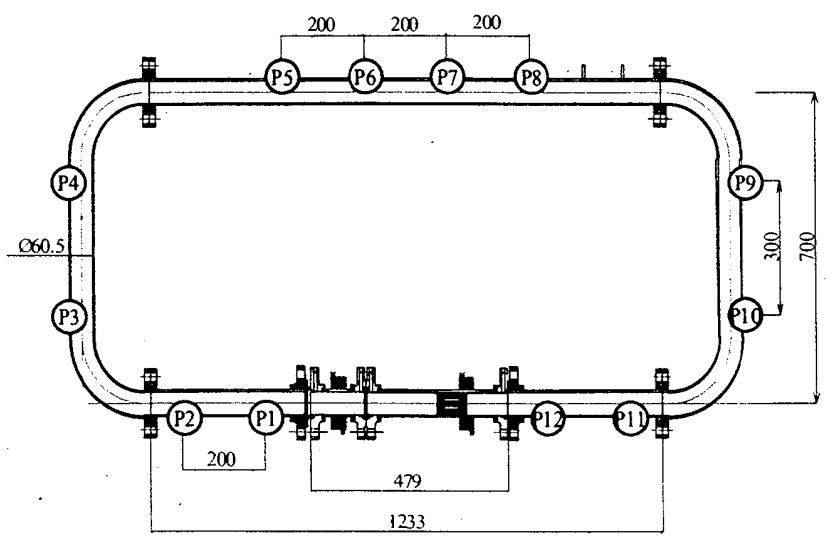

Fig. 1 Outline of thermoacoustic engine 
3. 仕様・設計

\section{1 リニア発電機の仕様}

まず，全体構成であるが，リ二ア発電機の場合，その原理 上，可動子の振動が発生するために，システム全体に振動に よる影響を与えることがある。そのため，通常は動吸振器な ぞを取り付け，振動を低減化する対策が採られる．熱音響発 振器の周波数は，さまざまな条件によって変化するため，動 吸振器による振動低減化は困難であり, 二台のリニア発電機 を対向して設置することにより，振動を発生させない構成と した.

出力は，現在の実験結果では $75 \mathrm{~Hz}$ に扮いて数十ワット程 度である. 今後の改良により出力の増加が見込まれているた め，最大出力は $100 \mathrm{~W}$ とした。ただし，上に述べたように対 向型としたために，発電機 1 台の出力は $50 \mathrm{~W}$ である.

リニア発電機の方式は，通常の可動磁石型リニア発電機之 した．可動コイル型の方が，スビーカとしても利用されてい るなど一般的である。しかし，可動磁石型と比較して効率が $70 \%$ 程度しか見込めず，かつ容積も大型になるため，可動磁 石型を選択した。目標効率は $90 \%$ 以上である。

可動磁石型でも，磁石と磁気回路を形成する鉄芯を一体構 成の可動子とする場合と, 磁石のみを可動子とするする場合 があり，それぞれ一長一短があるが，今回は，純粋に磁石だ けを可動子とした。これは，振動の周波数が高くても発電機 が対応できるようにできるだけ，可動子の重量を軽くするた めである。概略を図 2 に示す。

可動子は希土類永久磁石であり，フレクシャースプリング によって支持されており, 摺動部は存在しない構成である. 固定子は，軟磁性材料であり，渦電流損失を小さくする構成 となっている．可動子のストロークは，低格である $75 \mathrm{~Hz}$ に おいて $5 \mathrm{~mm}$ とした.

これらの仕様をまとめて，表 1 に示す.

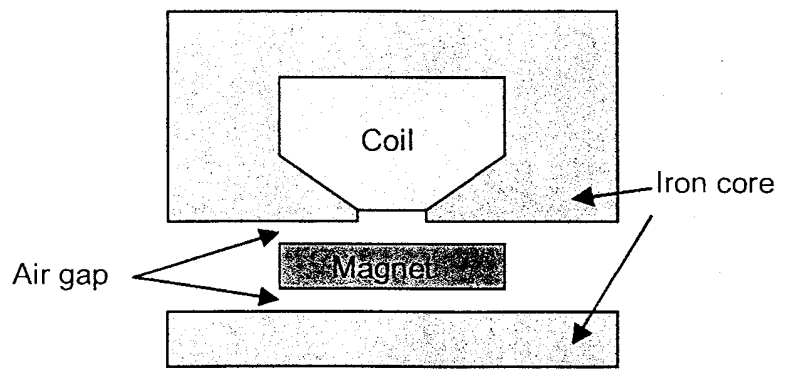

Fig. 2 Configuration of the linear alternator.

Table 1 Specifications of the linear alternator

\begin{tabular}{ll}
\hline Type & $\begin{array}{l}\text { Moving magnet } \\
\text { Opposed piston configuration } \\
\text { Argon, Air }\end{array}$ \\
Working gas & $300-600 \mathrm{kPa}$ \\
Mean pressure & $75 \mathrm{~Hz}$ \\
Rated frequency & $5 \mathrm{~mm}$ \\
Piston stroke & $\mathrm{Nd}-\mathrm{Fe}-\mathrm{B}$ type \\
Magnet material & $50 \mathrm{~W}$ at $5 \mathrm{~mm} / 75 \mathrm{~Hz}$ \\
Output power & $50 \mathrm{~W}$ at $3.5 \mathrm{~mm} / 150 \mathrm{~Hz}$ \\
& $90 \%$ \\
\hline
\end{tabular}

\section{2 リニア発電機の設計}

リニア発電機の電磁気回路の設計について述べる. 基本設 計では, バーミアンス法により簡単に概略寸法を求め, 詳細 設計は有限要素法解析ソフトウエアを用いて行った，有限要 素法解析は 2 次元軸対称の動解析で行い, 形状と効率の最適 化を行った。

先に述べたように，可動子はフレクシャースブリングで支 持されているが，可動子の永久磁石と固定子の間には，磁力 によるかなり強力な吸引力が生ずる. そのため, フレクシャ 一スプリングは, この吸引力に対抗できるだけ十分な強度が 必要である.また，あまり過大な力がかかると寿命に大きな 影響を与える. そのため, フレクシャースブリングの機械強 度についても，電磁場解析と同様に有限要素法解析を行った。 電磁場解析によって求められた吸引力を, 機械強度解析の入 力とし，フレクシャースブリングの設計を行った.

また, 可動子の振動周波数は動作ガスの自励振動の周波数 によって決まるが, 出力の取り出しに重要な位相遅れは，発 電機の固有振動数が大きな要因となる.この固有振動数は， そのときの負荷抵抗などによっても変化し，機械系（可動子 重量, フレクシャースブリングのばね定数など）と電磁気系 (コイルのインダクタンス，負荷抵抗なぞ）を同時に考慮す る必要がある.この解析は, 既報のように, 電磁気系を等価 質量, 等価減数定数などに置き換えることによって実施した

図 3 に，設計したリニア発電機の断面図を示す。本発電機 法, $600 \mathrm{kPa}$ 程度の圧力環境で運転されるため圧力容器に封入 される構成となっている.ただし, 発電機ユニットと圧力容 器は独立としており, 簡単に取りはずことが可能な設計とな っている。

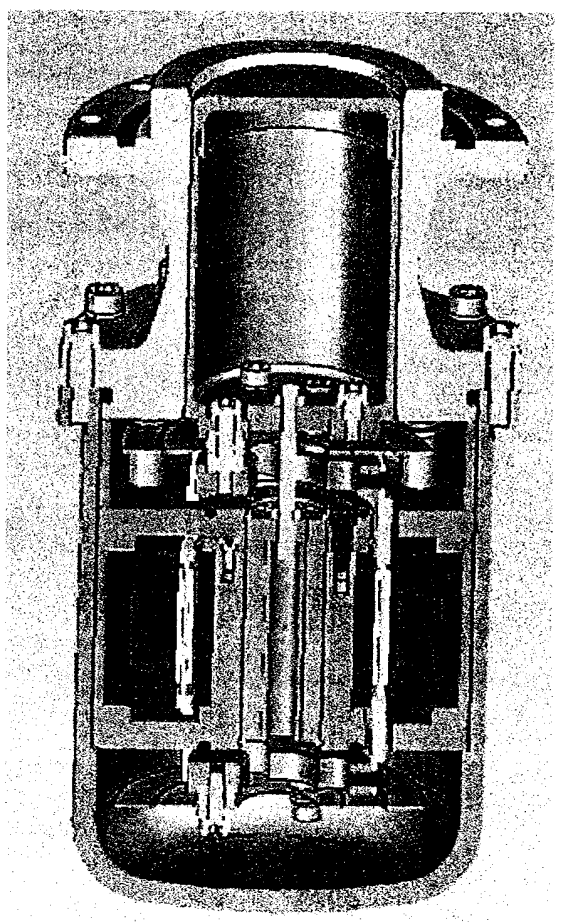

Fig. 3 Cross section of linear alternator (First generation) 
4. 試作と予備試験

\section{1 試作}

次に，試作と予備試験を行った。試作したリニア発電機と 熱音響エンジンとのインターフェイスユニットの外観を図 4に示す.

発電機コアは，可動子，固定子，コイルおよびフレクシャ ースブリングから構成されており, ビストンや圧力容器と独 立した構造となっている. 発電機コアの両端にあるフレクシ ャースブリングが可動子磁石を支持している.

この発電機コアに, ビストンを取り付け, 圧力容器に㨂入 したものが発電機ユニットである. 発電機ユニットには, 計 測用の圧力計と熱電対が取り付けられている.また, 可動子 のストロークを計測するために作動トランスが内蔵されて いる.この作動トランスは, 通常のリニア発電機よりも高速 で動作する本発電機に対応した, 位相遅れのほとんど無い高 速タイブである.

発電機ユニットは, インターフェイスを介して, 熱音響エ ンジンに接続される.インターフェイスの両側に発電機ユニ ットを取り付けられる構造となっており，対向型とすること により振動をキャンセルしている。

\section{2 予備試験と改良}

次に, 予備試験を行った。予備試験は, 発電機ではなくア クチュエータとしてモータリングさせることにより，その入 力仕事を計測し，各種の損失を把握した。

その結果，いくつかの問題点が明らかになつた。 その最大 のものは，ビストンとシリンダの接触であった。可動部全体 はフレクシャースブリングで支持されているため, ビストン はシリンダとほとんど接触しない構成でるが, 高速で動作さ せると，横方向の振動が発生し，ビストンがシリンダに接触 し，最悪の場合融着することがあった，そのため，中空の SUS 製であったビストンおよびその取り付け部材を樹脂製 のものに再設計を行った，改良したビストンを図 5 に示す。
これにより，接触はほとんど発生せず，また，発生しても融 着の危険は排除された. な挔，可動子の重量が大幅に変化し たため,フレクシャースブリングを再設計した。

また，電磁気系にもいくつかの改良を行った．可動子の永 久磁石の固定方法を改良したこと, コイルの巻き方を見值し て，線積率を向上したことが，主な改良点である.
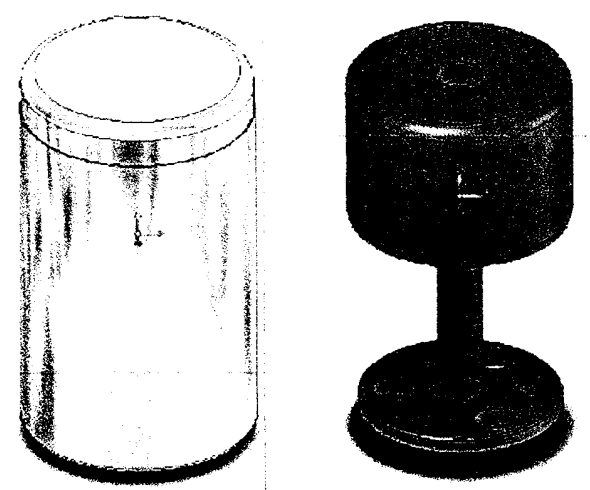

Fig. 5 Design modification of piston material

4. 性能試験

4.1 リニア発電機の試験方法

まず，リニア発電機単体での性能試験を実施した。この試 験には，リニア発電機試験装置 ${ }^{3)}$ を用いた。用いた計測シス テムの外観を図 6 に示す.

性能試験ではリニア発電機に接続した負荷抵抗の值を設 定值に固定し, 徐々に可動子ストロークを增加させることに よって行った．本来ならば定格である $5 \mathrm{~mm}$ までの計測を実 施すべきであったが，今回の試験では，4.5mm までとしてい る.これは $5 \mathrm{~mm}$ を超えると可動子とストッバーが接触し，

To thermoacoustic engine

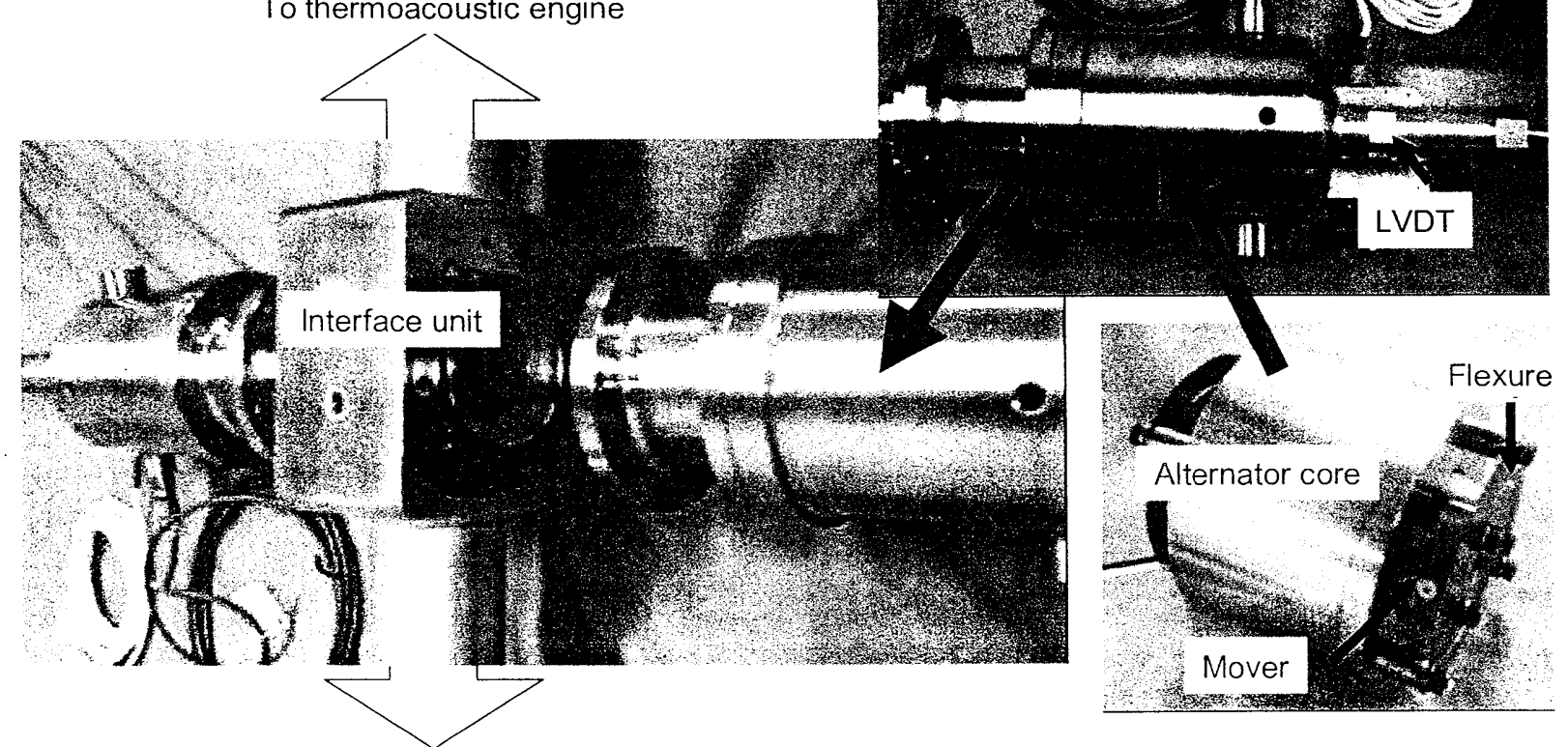

To thermoacoustic engine

Fig. 4 Configuration of linear alternator 
破損する場合があったためである.これは単独で運転してい る場合は問題ないが，リニア発電機試験装置によって機械的 に外部から駆動する場合, ストッパーに接触しても, 試験装 置が強制的に駆動してしまうためである.

運転周波数は, 定格周波数である $75 \mathrm{~Hz}$ を中心に前後の周 波数でのデータを取得した。 また，今回は，エアベアリング は用いずにリニア発電機のフレクシャースブリングをその まま用いて，可動子を支持している.

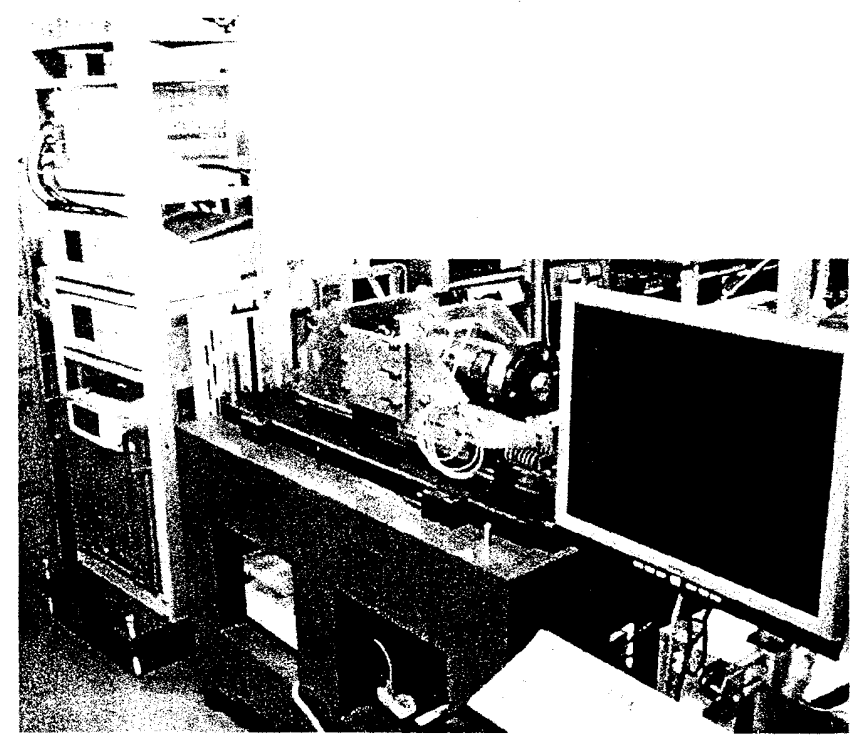

Fig. 6 Schematics of the linear alternator test system

\section{2 リニア発電機の試験結果}

図7は可動子ストロークとリニア発電機出力の関係を示し たものである. 周波数は $75 \mathrm{~Hz}$ で負荷抵抗の值は $60,80,130$, $150 \Omega$ あるる。卆れぞれについて，チューニングキャバシタ を抵抗と直列に挿入している. 出力はストロークの二乗に比 例して增加しており, 負荷抵抗が定格の $80 \Omega$ とき, ストロー ク $4.6 \mathrm{~mm}$ において $47 \mathrm{~W}$ の出力を達成した. 得られた出力よ り, 定格ストローク $5 \mathrm{~mm}$ のときの設計出力 $50 \mathrm{~W}$ は到達可能 と考えられる.また, 図 8 は効率の測定結果である. 効率は, ほとんどの場合で $80 \%$ を超えており, 定格周波数 $75 \mathrm{~Hz}$, 負 荷抵抗 $80 \Omega$ こきの効率は, $89 \%$ であった。これはわずかに 日標を下回っており，さらに改良が必要である。

\section{5. 結論}

熱音響エンジンに組み込むためのリニア発電機の設計と 試作を行った. その性能試験によって以下の結果が得られた.

1) ストローク $4.6 \mathrm{~mm}$ において $47 \mathrm{~W}$ の出力を達成した. 定格ストローク $5 \mathrm{~mm}$ に㧍いて，月標の $50 \mathrm{~W}$ は達成 可能と考えられる.

2）定格における効率は. $89 \%$ であり, 月標の $90 \%$ をわず かに下回った。

本発電機は, 熱音響エンジンに組み込むことが前提のため, 実際にエンジンに組み込んでシステム全体としての評価や 最適化が必要であり，早期に取り組む予定である.

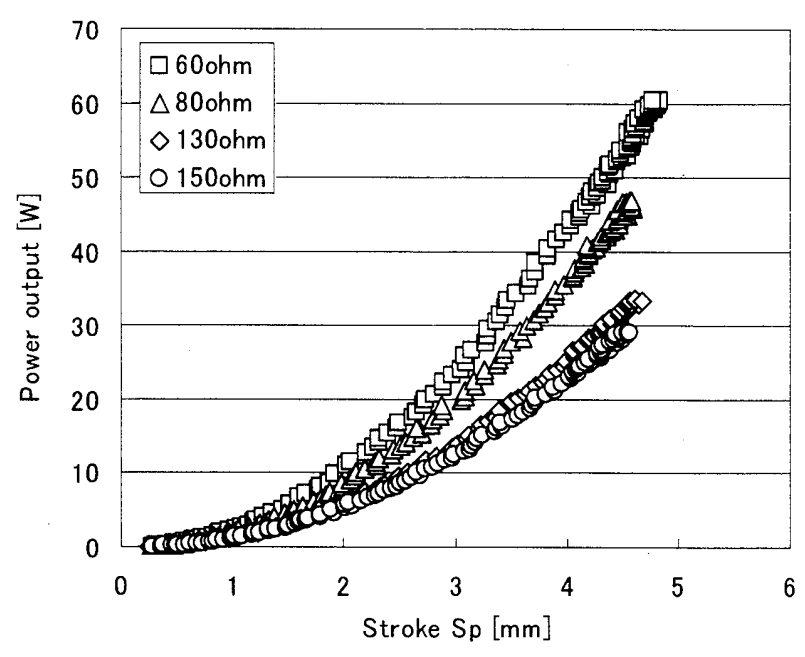

Fig. 7 Correlation between stroke and power output.

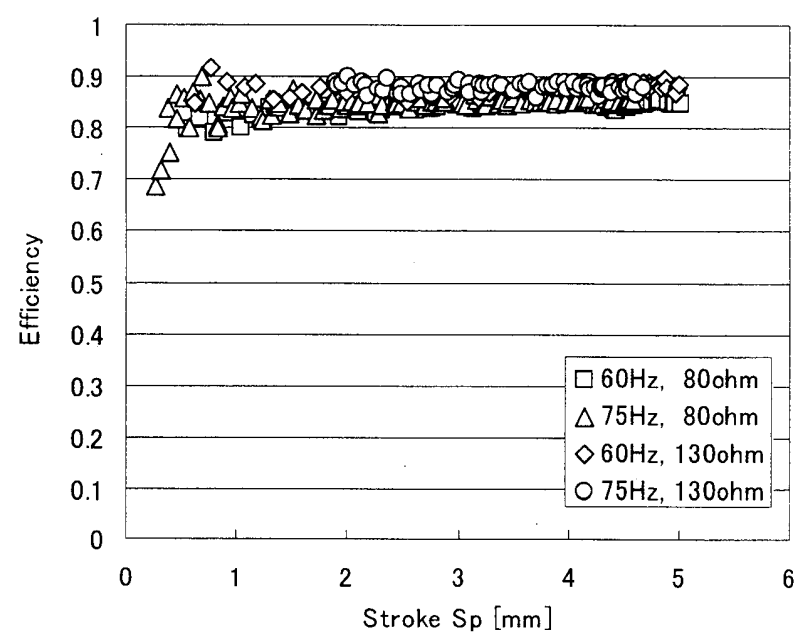

Fig. 8 Correlation between stroke and efficiencies.

[謝辞]

\section{[参考文献]}

1) Hoshino, T., et al., Development of Linear Alternator for Free Piston Stirling Engine, ISEC2007, D18, pp. 300-305, 2008.

2) 例えば 納富 他，ルーブ型熱音響エンジンの高効率 化と車両搭載に向けた研究, 第 46 回 日本伝熱シンボ ジウム 講演論文集, pp.116-117, 2009

3) 星野 他，新形式リニア発電機の性能試験，第 10 回ス ターリングサイクルシンボジウム講演論文集, A15 pp. 109-112, 2006. 